\title{
The Use Of The Money In The Deposits Banking. Some Questions Of Roman Law Within The Framework Of The Present Financial Crisis
}

Alicia Valmaña Ochaíta, Ph.D., University of Castilla-La Mancha, Spain

\begin{abstract}
The use of the deposited money has become a practice generalized in the present bank although it finds its origin in the Middle Age. The necessity to maintain a required cash reserve of the 100\% or on the contrary, with fractional reserve, continues nowadays being discussed by economists and jurists mainly in circumstances of financial crisis in which, after putting in circulation high amount of money, the cyclical retraction has taken place. In Rome, that also knew this kind of crisis, the money deposits were recognized; in them, the faculty of use derived from the own delivery of the simply counted money that it determined the transfer of ownership of it to the depositary. Nevertheless, the obligation of the depositary to give back the thing in the moment when it was required by the depositor, served as a barrier to the possibility of an effective use of this amount for the own business of the depositary.
\end{abstract}

Keywords: deposit of money, use, tantundem, banking activity, obligation of return.

\section{INTRODUCTION}

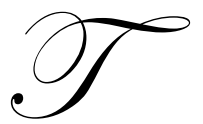

he varied and complicated commercial relations that currently take place within the banking scope, have caused in the last years a flow of extraordinary current money. The banks have put into the hands of the general consumer an amount of money hardly conceivable years ago, amount of money destined fundamentally to the personal and of families consumption; it has been the reality of the financial crisis the one that has shown how, independently of the more or less concrete reasons that they have caused it, the banking activity had, probably, transferred some limits.

The reasons of the crisis are different, and the particular conditions of each country cause that different reliefs appear in each one of them; however, some of them, are not new. From an external point of view to the banking organization, the individual/customer goes fundamentally to a bank by some of these three reasons: by trust, by necessity, or "gamble" with his money. Each one of those basic, primary reasons, corresponds with three also basic contracts in all banking business: banking deposits of money, credits, portfolio managements or, simply, investment. Independently of which, since we have indicated, the reasons of the financial crisis are more complex, it is reasonable to think about the necessity of a balance of these three elements so that the so call commercial bank can operate with guarantees for its clients.

However, historically this situation is not new. The Bank, after the definitive end of the Roman cycle with the death of the emperor Justinian in 565, and passed the years of the dark High Middle Age, mainly begins its resurgence in the Low Middle Age taking the banking business an extraordinary relevance centered in the commercial cities of the western Mediterranean arc and, indeed, becoming the general practice of the use of the money of the deposits for the accomplishment of other banking businesses, fundamentally loans to new clients (Huerta, p. 59ff, in an extraordinary work of reference to know the economic profiles relatives to the "irregular" deposit and the economic theories to this end, which emphasizes the theory of the $100 \%$ required cash reserve from, 
that the author defends; idem, the English translation, Huerta, 2005); it is born thus, the call bank with fractional reserve that supposes for some authors the true origin of the modern bank. (Usher, 1943, cit. in Huerta, 2006, pág. 53ff).

The key, therefore, is in the use of the money of the deposits conducted by the clients and the possibility of this use will depend, as logical, of the legal nature of the contract that underlies in each one of the relations established with the clients. In this sense, everybody knows the existence of similar contractual figures and how difficult is, in front of new commercial practices, to fit the economic fact in the normative fact. In our case, the handing over of an amount of money to a banker responds, in most of the occasions, to a safekeeping purpose which does of the figure, a deposit; nevertheless, the delivery of the money without sealing, simply counted, determines the transfer of ownership of the currencies with the obligation to give back to the client tantundem, which approximates the figure to the mutuum or loan.

Other many similarities and differences not less important between both contracts, approach or move away the delivery of counted money without sealing to a banker, on the part of a client, to one or another figure, and from the Roman time the discussion has settled down between the consideration of these businesses like mutua or deposits. The same discussion around the deposits banking has arrived until the present time: its legal qualification and the justification of the same one, as much from the civil optics (Lacruz, 1995), like mercantile (with current references of the Spanish jurisprudence, Valmaña M., 2007).

The fundamental question is in establishing to what extent the non fulfillment of certain characteristics of a contract does not determine its immediate perversion, and in this case it would be necessary to verify if it has fit in another contractual figure or not. However, a legal ordering can recognize the existence of irregular figures respect to its contract of reference; the irregularity appears like a natural solution to the non concurrence of some of the elements of a contract, allowing its improvement and regulation by the corresponding legal rules. The irregularity is the border line that allows us to maintain within the typical structure, in certain occasions, in certain contracts.

\section{PECUNIA NUMERATA AC DEPOSITA (Counted Money and deposited)}

The texts of the Roman jurisprudence gathered in the Digest of Justinian show to us how the jurists solved controversial legal questions, some real ones, in other cases, invented. Some of these texts gather solutions to problematic questions within a contract described previously, like for example, who assumes the risk of the loss of the thing - periculum- in a sale; in others, which treats, is to know in front of what contractual figure we are: what is difficult, is the qualification of the assumption in fact, object of the analysis. They are cases, for example, in which the doubt is if we are in front of a sale or a renting, a deposit or a mandate, a deposit or a mutuum. In these situations, any components of the analyzed assumption in fact shares and, as well, they are different of more than a contractual figure, reason why they do not have a easy fitting in one of the possible contracts; this happens, evidently, in contracts that show border lines not very noticeable with others, in certain circumstances.

In other words, the fact that the sale and the renting can differ without problems at theoretical level, does not prevent that it be difficult to describe the facts in which we are confronted, in certain circumstances -for example, D. 18, 1, 65 ${ }^{1}$; Gaius, Institutiones, III, 145, 146, and 147 -.For that reason sometimes, the difficult thing is not to interpret the rule, but the facts.

In other occasions the process of qualification of facts can demand an interpretation of the normative assumption. This is the case that occupied to Roman jurists when it was understood that the assumptions relative to the delivery of money without sealing for the tantundem given back, escaped of the notissimos terminos of the deposit (Papiniano en D. 16, 3, 24; the expression was a success in the following centuries, Azo, Summa Codicis, III, p.22). That issue would come to be equivalent from the normative fact that we are speaking, since in the Roman Law does not exist a regulating (written) rule of the deposit contract, in strict sense.

\footnotetext{
${ }^{1}$ References with D., are from the Digest of Justinian; with C., Codex.
} 
Some texts of the classic jurists offer doubts about the recognition of a figure that exceeded the very wellknow limits of a deposit and which was a common banking practice within the deposit contract. In some cases this is due to the compilers in the justinianea age, whose accept without doubt the "irregular" deposit, changed and altered the sense of the texts (interpolations) with the aim to insist on the acceptance of interests' agreement, fundamentally. Excluded the "nothingness" legal that would hit against the aim of the classic jurists who raise their cases under the prism of "legal evaluable relations", the consideration of these relations as mutuum also offers difficulties and would exceed, as well its very well-know limits - those of the mutuum- so that, quid est enim aliud commendare, quam deponere? (D. 16, 3, 24, id. Ulpiano in D. 50, 16, 186, "commendare nihil aliud est quam deponere". With this interpretation of commendare, it is doing, evidently, something more than a literal interpretation of a term that appears in the letter that Lucio Ticio writes to Sempronio which appears in D. 16, 3, 24; with the letter is doing a clear reference to which has been the intention of the parts at the time of establishing the legal relation at issue, which is reaffirmed with the following expressions relative to the return "immediately, when and where you want" quando voles et ubi voles, confestim tibi numerabo- that hit against the mutuum concept. Vide amply, with argumentation and bibliography, Valmaña, 1996, pág. 69ff).

At the classic time the discussion turns around two questions: in the first place, the contrast between "ready money" or "cash" - numerare or adnumeratio-, referred to generic expressions like numus, penes, pecunia- opposite to "sealed money" - sacculum vel argentum signatum, pecunia clausa vel obsignata- and the consequent possibility to use, or not, of the money and, secondly, the use of the money from a permission ab initio or ex intervallo (subsequent) concurrent in a deposit. Both questions move away this legal relation of the contract of "ordinary" deposit and their approach it figures like the mutuum, which has caused an intense discussion in the romanístic doctrine. Mainly, -and without exhaustiveness spirit- it could be said that there is a theory that considers irregular deposit not accepted by the classic jurists (Longo, 1906); a intermediate theory: some jurist would have accept the figure, and others not (Segrè, 1907) (Vigneron, 1984) (Litewsky, 1974 y 1975) and a theory that accepts in general cases, the consideration of the irregular deposit as deposit (Adams, 1962) (Klami, 1969), besides the other I will mention ahead.

a) The first indicated question is also the one that, chronological, serves as discussion the Roman jurists. The ordinary deposit was thought for non fungible goods; nevertheless, the activity to deposit money - fungible good by excellence - was, without any doubt, very frequent. For this reason, the money had to remain "non fungiblilized" through artificial ways as it would be to seal it or to lock up it in closed boxes perfectly identified and, therefore, distinguishable. From this point of view, the fact to have to make non fungible the thing object of deposit to fit within the regime of the ordinary or regular deposit, implied an added activity, a plus opposed to the irregular deposit in which the money was given simply counted, so that equal amount was given back.

In this sense, we found a group of text of Roman jurists - some of pre-classic age- in which the delivery of fungible goods is accepted as object of contracts that were conceived for non fungibles goods, in such a way that the obligation to give back the idem, the same given good, falls to give place the obligation to give back the tantundem.

The testimony of Alfeno Varo, jurist of the republic time, in its well-known text on the vessel of Saufeyo, gathered in D. 19, 2, 31, speaks to us about the possibility of a locatio operis "irregular" -rerum locatarum duo genera ese [...] ut aut idem redderetur, [...], aut eiusdem generis redderetur-. The raised case is the one of the transport by sea of different amounts of wheat, fungible merchandise, that to each other are confused, and of that are different owners -In navem Saufeii cum complures frumentum confunderant-. The problem that considers the jurist is the fulfillment of the obligation of return of the wheat by the ship owner, being the ship casualty lost with part of the load, once he had given back to a part -Saufeius uni ex his frumentum reddiderat de communi, et navis perierat-; the solution of the jurist is that he gave back correctly -recte datum- since he was forced to give back equal amount tantundem-. This possibility is extended to the deposits in relation to the obligation of restitution of the given goods -Idem iuris esse in deposito-.

The justification of this decision is in the transfer of ownership of the fungible goods to Saufeyo, by the fact to give them without identifying, without sealing -frumentum confunderant; pecuniam numeratam neque clausam, neque obsignatam, sed adnumeraret-. This is the fundamental question in the consideration of the deposit of money by part of the Roman jurisprudence, also the classic one. The fact of the delivery of simply counted money, without 
sealing, causes a series of legal consequences, inevitably logic: the transfer of ownership of the money to the depositary and, consequently, the faculty of use of the money, which remains integrated as a faculty of the ownership right on the good and, as any faculty, could be materialized or not. The obligation of return, in these cases, is fulfilled with the delivery of equal amount of currencies -or even, the same ones in case they stayed without been mixed with others (Coppa-Zuccari, 1901, pág. 25)-.

For that reason the depositary who uses the given money simply counted -pecunia numerata- does not commit furtum usus, the same way Saufeyo cannot either be condemned by the action of withdrawal of load by the amounts not given -quaesitum est, an ceteri pro sua parte frumenti cum nauta agere possunt oneris aversi actione-, because he acted correctly when giving one part of the wheat mixed in the common mass, since the wheat had become his property - secundum quae videri triticum factum Saufeii, et recte datum-.

The text of Alfeno Varo makes reference to two classes of res locatae (Longo, 1906, p. 139) that it extends to the two ways in which we can have the res deposita, so that, the fundamental question is the nature of the given thing that produces the consequences whose before we alluded, but that, at any moment, affects the nature of the celebrated legal contract, that the jurist understands like a locatio at any moment or as a deposit and what, of course, is an only contract, an only legal relation (Valmaña, 1996, p. 49). To such an extent the rules of the renting contract or of the deposit- remain that, to some authors, lost all the load, Saufeyo would have been released of all liability because there was no negligence in the loss of the good (Bonifacio, 1948, p. 108, n.54).

Other texts touch upon to the idea of the transferring of ownership with the delivery of fungible things (Valmaña, 1996, p. 22ff. in relation to Gayo III, 147, Pomponio in D. 34, 2, 34 and Javoleno in D. 18, 1, 65), but is the text of Alfeno the one that, with greater clarity, gathers the original concept that from the deposit of money the Roman jurists had: si quis pecuniam numeratam ita deposuisset, ut neque clausam, neque obsignatam traderet, sed adnumeraret, nihil aliud eum debere, apud quem deposita esset, nisi tantundem pecuniae solvere.

This conception of the money deposit seems already assumed by the classic jurists. Thus, Papiniano, in the gathered text already mentioned in D. 16,3,24, speaks to us of a delivery of one hundred currencies that the slave of Sempronio, Stico, counting them, entrusts Lucio Ticio who is obliged himself to give back them when and where Sempronio wants, immediately -Centum numos, quos hac die commendasti mihi annumerante servo Sticho actore, esse apud me [...] quae quando voles, et ubi voles confestim tibi numerabo-. Appears again the idea of counted money as much in the delivery (annumerante) like in the return (numerabo); also, the facilities given for the return of the money indicate the own activity of bankers (vide Demóstenes contro Afobo, when speaks about a banker who had put an announcement in his establishment assuring that he would give back the deposited money even at night; extensively, Valmaña, 1996, p. 71ff) and that, of course, would go against an interpretation of the assumption in fact like a pure deposit in which idem is given back (Segrè, 1907, p. 223).

Jurists like Papiniano or Paulo, on the base of the recognition of pecunia numerata ac deposita as deposits although irregular, as it would be denominated later- would have been asked themselves, taking a step forward in relation to the pre classical jurisprudence, about one of the fundamental problems: if, from these relations, it was possible to demand the payment of interests - Quaeritur propter usurarum incrementum (D. 16, 3, 24) or Quaero, an usurae peti possunt (D. 16, 3, 26, 1)-.

Their answer was to accept only the interests post moram, that is to say, since the moment at which the return of tantundem has not taken place, once it has been required to him. Before incurring on delay, does not seem to be accepted a pactum in continenti of interests that comprised itself into the own contract of deposit (Brasiello, 1956, p. 502 and amply, Valmaña, 1996, p. 77). Nevertheless, the same fact of asking themselves if is possible to demand interests in the deposits of counted money, implies that it was a current question to the classic jurisprudence; some authors even maintain that some jurists - Paulo- could have accepted the payment of interests through actio depositi, at least on the base of the officium of the judge, who would have considered the agreement on the interests like matter derived from the good faith (Gordon, 1982, p. 379ff); however, also in principle, in the case of the money deposit the depositary lends a benefit to the depositor, until the extent of offering to have the money available quando voles, et ubi voles. The use of the money by the depositary is something inherent to datio rei: since the money is deposited without sealing, its use derives from the datio rei, necessarily, like an integrating element of the same, with no need of a special permission of use, or to provide any compensation. 
For this reason we found a greater number of justinianeas interpolations in these texts, focused fundamentally to recognize legal consequences that, at classic time, had not been admitted, as the pacts of interests adhered to money deposits, to emphasize the influence of the will of the parts, or the conception of the use of the money as subjective element and not only as objective element derived from datio rei -as it happened at the classic time-, with the consequent assumption of the idea of benefit of the depositary, valuable economically.

b). We said pages back that the second question in relation to the discussion on this subject is about the cases of use of the money from a permission ab initio or ex intervallo in a deposit. The fundamental texts in this question are those of the jurist Ulpiano; the assumptions of a permission of initial use appear gathered in D. 12, 1, 10 and D. $16,3,1,34$, and the permission of use ex intervallo and the effects that they have on a deposit contract, in D. 12, 1, 9,9 .

The permission of use ab initio -Quodsi ab initio, cum deponerem, uti tibi, si voles, permisero [...] o Si pecuniam apud te ab initio hac lege deposita sit, ut, si voluisses, uteretis [...]-does not transform the original contract of deposit into the one of mutuum, but that the legal action to protect the contract only changes in case the precedent and optional condition was verified - creditam non ese, antequam mota sit, quoniam debitum iri non est certum o priusquam utaris, depositi tenebris -. This verification is only possible by the external act of the breaking of seals, acceding materially to the currencies (Brasiello, 1956, p. 486). As we can see, Ulpiano starts in these two texts of an assumption of ordinary deposit, this is, of sealed deposit; the difference, in relation to their legal effects, with a deposit - irregular- of money is that, in this one, the use of money is something that naturally derives from the delivery of the simply counted money, reason why used or not the amount, the effects of the contract will occur in any case, because the fundamental element in the irregular deposit is not the use, but the obligation to give back tantundem (accompanied of the safekeeping purpose that supposes its cause). In the assumptions of Ulpiano ordinary deposit-, the effective use is the transcendental element that causes the change from an action to another one, the moment in the depositary confirms his "adhesion" to the new contract.

In the cases of or a posteriori o ex intervallo permission -deposui apud te decem, postea permiso tibi utiUlpiano also starts of an assumption of deposit of sealed money -for that the use of the expression antequam moveantur that alludes to the removal of seals-. In fact, assumption and solution are very similar to that we have seen in relation to the initial permission, with the difference of, now, the parts, depositor and depositary, are which seem to conclude a pact whose content is the possibility of using the money. This reason would be the one that would take to jurists like Nerva and Próculo to advance at the time of celebration of the pact the possibility of exercising the condictio -legal action to defend the contract of mutuum- without having to wait for the effective use; the spirit of the depositary would have changed, into Marcelo's opinion, since from the text seems to be deduced that the permission of use has been authorized to depositary's requirement -animo enim coepit possidere [...] qui mutuam rogavit-.

The change from deposit -ordinary- to loan takes place by the relevance that takes the faculty of use that comes directly from the will of the parts (Bonifacio, 1948, p. 130); however, as we have already said, in the deposit -irregular- of money lacks this faculty of use emanated of the will of the parts: the use occurs as a tangential circumstance emanated of the transfer of ownership that takes place with the delivery of the simply counted money in a contract celebrated, not with the purpose of granting to the depositary the use, but the safekeeping of the thing that allows the return of the same amount of money (Bonifacio, 1948, p. 129).

Consequently, if the use is something derived naturally from the delivery of the counted money in which the transfer of the ownership has taken place, can the depositary use the money as he wants? Papiniano, in the assumption gathered in D. 16, 3, 25, 1, talks about the problem of a depositary that, having received money without sealing, with the obligation to give back solely the tantundem -Qui pecuniam apud se non obsignatam, ut tantundem redderet-, uses it in his own businesses or his own benefit -ad usos proprios convertit -. Although some authors see different interpolations in the text, I understand that the jurist would have tried to highlight the consequences of the unfulfilment of the obligation of return of tantundem, caused by the use of the money in his own businesses. This use is the one that puts to him in the situation of unfulfilment and for that reason, from being placed in delay, must pay the corresponding interest -post moram in usuras quoque iudicio depositi condemnandus est-. 
The main obligation of the depositary is the return of tantundem and, although the use of the money derives from his present condition of owner of it, the possibility always present that the depositor demands the return of the given money at any time, places him in a situation of most special danger of unfulfilment of the main obligation return- if he had used this money ad usos proprios. The situation in case of unfulfilment would be worst even more for the depositary because, being the deposit a contract of good faith, the iudex always could value the elements that surround to the unfulfilment, to increase the sentence, in addition to the claimableness of the interests post moram, that we just have seen.

The texts that we have seen until now, and others more whose analysis exceeds the intention this study, reflect the preoccupation of the Roman jurisprudence by an intense banking activity in which the legal relations between nummularii or argentarii and clients was more and more varied and complex, and to that the Roman Law had to give answer within the existing contractual structures (extensively, Torrent, 2007, p. 140ff). The preoccupation was not exaggerated. The texts reflect that the banking activity not always was developed of correct form and the classic jurists gather assumptions of bankruptcies of bankers (D. 16, 3, 7, 2 and D. 42, 5, 24, 2, for example); the trust that a banker woke up in his clients was the fundamental base so that certain contracts were celebrated: deposit always was a contract based on fides, and when the contract is "professionalized" with depositary/bankers the trust goes beyond the personal relation between the parts, being generated a fidem publicam, that has a certain social function (Pérez, 2000, p. 365). This is the reason that the depositors are considered in the Roman Law like creditors privileged in the cases of bankruptcy of a banker -In bonis mensularii vendundis post privilegia potiorem eorum causam esse placuit, qui pecunias apud mensam fidem publicam secuti deposuerunt (D. 42, 5, 24, 2)-, (amply, Pérez, El privilegio de los depositantes sobre el patrimonio del banquero en Derecho Romano Clásico, 2000, p. 805ff).

The bankruptcies of the bankers supposed the unfulfilment of the obligation to give back tantundem in the "irregular" deposits and their liability was demanded through actio depositi. The deposited trust in them for the safekeeping of their goods had been betrayed -remember the reference of Ulpiano in D. 42, 5, 24, 2 to fidem publicam or the one that appears in a rescriptum of Diocleciano $($ C. $4,34,8)$ relative to the obligation to fulfill the trust order that the depositary had accepted de implenda suspecta fidem-. Also they suppose the unfulfilment of the sealed deposits, unless remains identified the small bags of money -nummi exstantes- in which case, because not having produced transmission of the ownership, in no case can be confused with the goods of the banker, reason why the action for claim the ownership is the appropriate, as much if they are still under the detentación of banker (D. 42, 5, 24, 2), whatever if this one, committing a furtus usus, gave it in mutuum to a third (C. 4, 34, 8).

The liability by the unfulfilment in a contract of ordinary deposit approached, from the end of the classic age to the one of the deposit -irregular- of money, canalizing themselves both, probably, through the actio depositi, that allowed a high margin of sentence that each iudex decided to impose, in each case, by virtue of the good faith, next to the possibility of demand interests; actio furti would have fallen in front of actio depositi (Brasiello, 1956, p. 496, n.1) and from there, perhaps, the nonreference to the same one in D. 42, 5, 24, 2 and C. 4, 34, 8.

The aim of the classic jurisprudence in fitting these relations within the existing contractual figures disappears in the postclassic age, in which "the tendency of the postclassic vulgarism that looks at the problems from the economic perspective, without too much concerning the respect for the legal categories" (Díaz, 1987, p.62). The declivity of the banking activity from this time also would cause this distance of the legal perspective.

\section{CONCLUSION}

The use of the money is a natural consequence of the transmission of the ownership of the currencies that the depositor has given simply counted; nevertheless, the obligation of return of tantundem at any moment, even in some deposits quando voles et ubi voles, confestim, forced the depositary to maintain the amounts always available not to fall in risk of a unfilfilment that would take joined the demand of interests post moram. 


\section{AUTHOR INFORMATION}

Alicia Valmaña Ochaíta: Degree in Law by University of Alcalá (Spain) and PhD in Law by University of Castilla-La Mancha (Spain). Associate Professor at Roman Law (Public Law and Legal Science Department). Faculty of Legal and Social Sciences of Toledo. University of Castilla-La Mancha (Spain). E-mail: Alicia.Valmana@uclm.es.

Research Interest: Democracy. Democratic reforms in voting district in Rome. Contracts in Roman Law. Ownership in Roman Law. Language and Law.

\section{REFERENCES}

1. Adams, B. (1962). "Haben die Römer "Depositum Irregulare" und Darlehen unterschieden?", in Studia et Documenta Historiae et Iuris (28), p. 360-371.

2. Bonifacio, F. (1948). "Ricerche sul Deposito Irregolare in Diritto Romano", in Bulletino dell Istituto di Diritto Romano (49 y 50), p. 80-150.

3. Brasiello, U. (1956). "Aspetti innovativi delle costituzioni imperiali”, in, Studi in onore di Pietro Francisci (Vol. IV), p. 473-503).

4. Coppa-Zuccari, P. (1901). "Il deposito irregolare". Módena.

5. Díaz, A. (1987). "Estudios sobre la Banca Bizantina (Negocios bancarios en la legislación de Justiniano)". Murcia. Universidad de Murcia.

6. Gordon, W. M (1982). "Observations on «depositum irregulare»", in Studi in onore di Arnaldo Biscardi (Vol. III), p. 363-372).

7. Huerta, J. (2005). "Money, Bank Credit and Economic Cycles". Alabama. Luwdwing von Mises Institute. University of Auburn.

8. Huerta, J. (2006). "Dinero, Crédito bancario y Ciclos Económicos" ( $3^{\mathrm{a}}$ ed.). Madrid. Unión Editorial.

9. Klami, H. T. (1969). "Mutua magis videtur quam deposita. Über die Geldverwahrung im Denken der römischen Juristen". Helsinki.

10. Lacruz, J. L. (1995). "Elementos de Derecho Civil” ( $3^{a}$ ed., Vol. II). Barcelona. José María Bosch editor.

11. Litewsky, W. (1974 y 1975). "Le Dépôt Irrégulier", in Revue Internationale du Droit Romain (21-22).

12. Longo, G. (1906). "Appunti sul Deposito Irregolare", in Bulletino dell Istituto di Diritto Romano "Vitorio Scialoja" (18), p. 12ff.

13. Pérez, M. P. (2000). "El privilegio de los depositantes sobre el patrimonio del banquero en Derecho Romano Clásico" in Estudios de Derecho Romano en memoria de Benito $M^{a}$ REIMUNDO YANES (p. 805ff) . Burgos: Universidad de Burgos.

14. Pérez, M. P. (2000). "La Bonorum Venditio. Estudio sobre el Concurso de Acreedores en Derecho Romano Clásico". Madrid. Mira ed. and UAM ed.

15. Segrè, G. (1907). "Sul Deposito Irregolare in Diritto Romano" in Bulletino dell Istituto di Diritto Romano (19), p. 197-234.

16. Torrent, A. (2007). "Moneda, Crédito y Derecho Penal Monetario en Roma" (s.IV a.C.- IV d.C.), in Studia et Documenta Historiae et Iuris (LXXIII), 111-158.

17. Usher, A. P. (1943). "The Early History of Deposit Banking in Mediterranean Europe”. Cambridge. Massachusetts. Harvard University Press.

18. Valmaña, A. (1996). "El Depósito Irregular en la Jurisprudencia Romana”. Madrid. Edisofer.

19. Valmaña, M. (2007). "El Contrato de Depósito", in Soluciones de Derecho Mercantil (e-book ed.). El Derecho Editores.

20. Vigneron, R. (1984). "Résistance du droit Romain aux influences hellénistiques: le cas du dépot irrégulier", in Revue Internationale du Droit Romain (31), p. 307-324. 
NOTES 